\title{
НАПРЯМИ РОБОТИ З ІН’ЄКЦІЙНИМИ СПОЖИВАЧАМИ НАРКОТИКІВ
}

\author{
I. В. Явкіна \\ Миколаївська міська лікарня \\ Тернопільський національний медичний університет \\ імені І. Я. Горбачевського МОЗ України
}

\begin{abstract}
У статті розкрито основні напрями роботи з ін'єкційними споживачами наркотиків. Узагальнено роботу служби «Довіра».
\end{abstract}

\section{AREAS OF WORKING WITH INJECTING DRUG CONSUMERS}

\author{
I. V. Yavkina \\ Mykolaiv City Hospital \\ I. Horbachevsky Ternopil National Medical University
}

The article describes the main directions of work with injecting drug users. The work of the Trust service is generalized.

Вступ. Згідно з даними МОЗ України, нині кількість наркозалежних, які перебувають на диспансерному наркологічному обліку, складає більше 84 тис. осіб (близько 179 на 100 тис. населення, з яких 117,7 чоловіки, 61,3 - жінки). ще більше 32 тис. осіб (69 на 100 тис. населення) перебувають на профілактичному наркологічному обліку. В Україні серед споживачів ін'єкційних наркотиків кількість молодих людей віком 24 років становить від 42 до 58 \%. Рівень поширеності вживання наркотичних речовин вищий на півдні та сході України, нижчий - на заході країни.

Згідно із Законом України «Про заходи протидії незаконному обігу наркотичних засобів, психотропних речовин і прекурсорів та зловживанню ними», наркоманія - хворобливий психічний стан, зумовлений хронічною інтоксикацією внаслідок зловживання наркотичними засобами, що віднесені до таких Конвенціями ООН чи Комітетом з контролю за наркотиками при Міністерстві охорони здоров'я України, і який характеризується психічною або фізичною залежністю від них.

Основна частина. У країнах Західної Європи та в США поняття «наркозалежність» визначається

(c) І. В. Явкіна, 2020 як психофізіологічний стан залежності людини від наркотичних засобів та психотропних речовин, які викликають у неї оманливе відчуття благополуччя, веселощів, сп'яніння, наркотичного сну. Розвиваючись, залежність послідовно проходить кілька стадій - соціальну, психологічну, фізіологічну.

Соціальна залежність характеризується тим, що людина ще не почала вживати наркотичні речовини, але потрапила в середовище тих, хто їх вживає. Вона приймає стиль поведінки, ставлення до наркотичних речовин і зовнішні атрибути групи. У такій ситуації людина часто внутрішньо вже готова почати вживання наркотичних речовин. Неодмінною умовою цієї стадії $\epsilon$ наявність групи, де вживають ті чи інші наркотичні речовини.

На стадії психологічної залежності змінюється поведінка людини. Вона починає вживати наркотичні речовини з метою відчути певні емоції. Психологічна залежність може сформуватися навіть після одногодвох прийомів наркотичних речовин.

Фізіологічна залежність настає після того, як організм включає наркотики у процес обміну речовин. Це - непереборна фізична потреба, яка виникає в результаті постійного або періодичного вживання 
наркотиків. У цьому випадку різке припинення вживання наркотичної речовини викликає фізичний розлад різного ступеня тяжкості, який називається абстинентним синдромом, або синдромом відмови. На цій стадії людина потребує лікування.

Також використовують поняття співзалежність спроба подолання проблеми, з якою стикається близька людина. Така залежність може приносити радість, коли людина намагається жити турботами рідних, бере близько до серця зміну настрою близьких, їхні слова і вчинки. Але якщо у взаємини втручається наркотик, то він порушує будь-яку гармонію. Важливим $\epsilon$ врахування ознак, що характеризують співзалежного: перебільшення значимості своєї сили волі; увага сфокусована на залежному; неусвідомлення власних почуттів, відсутність контролює їх появу; низька самооцінка; відчуття втоми, тривоги, страху, неврівноваженості; соціальна та емоційна ізоляція.

Всесвітньою організацією охорони здоров'я спільно з іншими агенціями ООН розроблено важливі принципи профілактичних заходів, які узагальнили позитивний досвід багатьох країн. Максимальний ефект досягається, коли ці принципи застосовують комплексно. До них належать: інформаційна роботай освіта споживачів ін'єкційних наркотиків; забезпечення доступності для споживачів ін'єкційних наркотиків $(\mathrm{CIH})$ соціальних служб і служб охорони здоров'я; безпосередня робота в середовищі СІН (вулична робота, залучення до програми волонтерів з представників споживачів ін'єкційних наркотиків); надання споживачам ін'єкційних наркотиків засобів безпеки - стерильного ін'єкційного інструмента, матеріалів для дезінфекції, презервативів для захищеного сексу; створення можливості для споживачів ін'єкційних наркотиків отримати замісну терапію.

Згідно з нормативно-правовою базою, в багатьох містах України створюється служба «Довіра» по роботі з ін'єкційними споживачами наркотиків [2]. Це спеціалізоване формування, яке створюється спільно медичними установами й центром соціальних служб для сім'і, дітей та молоді для надання медичних, психологічних, соціальних послуг ін'єкційним споживачам наркотиків та членам їхніх сімей. Метою створення та діяльності служби «Довіра» є запобігання поширенню ВІЛ-інфекції серед ін'єкційних споживачів наркотиків.

Форми та методи роботи медиків у службі «Довіра» спрямовані на формування у клієнтів навичок безпечної поведінки та усвідомлення ризику зараження на ВІЛ-інфекцію при ін'єкційному вживанні наркотиків, залучення ін'єкційних споживачів до профілактичних програм, створення соціально-психологічних умов для відмови клієнтів від вживання ін'єкційних наркотиків. Більшість профілактичних програм, які діють в Україні, використовують різні форми. Переважно це поєднання послуг стаціонарної служби «Довіра» та польової вуличної роботи. У деяких містах та регіонах поєднують мобільні пункти з вуличною роботою. Як правило, такий мобільний пункт розміщують в мікроавтобусі. У ньому обладнують місце для обміну шприців, для консультування та надання первинної медичної допомоги. Мобільний пункт відрізняється від польової роботи тим, що бригада має мікроавтобус, спеціально обладнаний гучномовцем транспортний засіб, в якому є кабіни для консультування.

у роботі служби "Довіра» виокремлюють такі cmadii:

Стадія І. Підготовка працівників різних спеціальностей для роботи в службі «Довіра». Мета: формування команди (підбір та підготовка тренерів, волонтерів), планування роботи; засвоєння тренерами і волонтерами основ медичної допомоги, організаторської роботи тимчасового колективу - групи взаємодопомоги та взаємопідтримки; вміння визначити рівень сформованості якостей особистості.

Стадія II. Створення самокерованої групи. Мета: формування медичними працівниками та фахівцями центрів соціальних служб для сім'ї, дітей та молоді разом із споживачами ін'єкційних наркотиків груп взаємодопомоги та взаємопідтримки; планування їхньої роботи. Принципи роботи: врахування вікових та психологічних особливостей, повага, відвертість, довіра, толерантність, індивідуальне планування самостійної роботи над собою тощо. Дотримання цих принципів посилює зміст та результативність роботи, оскільки клієнти самі встановлюють норми та правила роботи у групі, визначають цілі та завдання, аналізують коло проблем, ухвалюють методи та прийоми їх розв'язання.

Стадія III. Підготовка створеної групи до спільних дій. Мета: усвідомлення кожним членом групи взаємодопомоги відповідей на запитання: що, чому, для чого, у який спосіб, чого я вартий?

Cтадія IV. Дії групи. Мета: організація конкретної допомоги (перехід від обговорення до вирішення проблем). 3 метою емоційного засвоєння певної інформації використовують ігрові вправи та ситуації, в яких передбачається виявлення знань учасників, особистих стереотипів поведінки, ціннісних наста- 
нов, обговорення з акцентуванням уваги на думках, переживаннях, почуттях, емоціях, які виникли під час гри. Вправи на асоціацію передбачають створення кожним учасником асоціативного ланцюжка, пов'язаного з певним явищем, поняттям, ситуацією, та обговорення з метою пояснення своєї думки. Медичному працівнику доцільно відслідковувати емоційні моменти обговорення результатів роздумів, висновків учасників, щоб з'ясувати, чи усвідомлюють вони нові знання, чи змінюється мотивація їхнього здобуття, чи $\epsilon$ спроби практично застосувати здобуту на заняттях інформацію.

Стадія V. Група діє самостійно. Мета: практичне застосування принципу емпауерменту - перехід до самостійності. Група продовжує визначати взаємозв'язки між запитаннями: що, чому, для чого, яким чином? Учасники діють активно, вчаться контролювати та критично оцінювати власне життя, сприймати себе очима інших; розвивається їхня самооцінка, усвідомлення себе, своїх дій. Медичні працівники на цьому етапі залучаються до роботи групи як супервізори, фасилітатори, консультанти.

Стадія VI. Аналіз результативності роботи. Mema: підсумок ефективності роботи та доцільності діяльності групи. Медичний працівник - керівник групи повинен бачити й оцінювати ефективність спільної партнерської роботи - своєї та групи як єдиного цілого, аналізувати результати роботи, сприяти визначенню висновків, складанню планів на майбутнє (обговоренню цілей життя). Досягнення наміченої мети - створення групи, яка може самостійно надати кожному учаснику практичну допомогу, навчити самодопомозі. У групі обговорюють такі питання: знання, усвідомлення, поведінка, профілактика, відповідальність за власне здоров'я і життя; відповідальність за здоров'я інших людей; плани на майбутнє (мета, завдання), ресурси (знання), усвідомлення дій тощо.

Остання стадія підсумовує доцільність проведеної роботи, а саме:

- чи вдалося створити групу, яка насправді може надати кожному учаснику практичну допомогу;

- чи навчилися учасники групи самодопомозі;

- чи можуть вони продовжувати самостійну профілактичну роботу зі споживачами ін'єкційних наркотиків;

- чи сформована у них відповідальність за власне здоров'я та здоров'я інших людей;

- чи розуміють вони, що набуті знання, усвідомлення ризику ВІЛ-інфекції, зміна поведінки, прихильність однодумців у групі - найбільше їхнє надбання;
- плани на майбутнє (постановка цілей, аналіз відчуттів).

Учасники групи визначають зв'язки між досягненням та досвідом, поступово переходять до самоконтролю. Стимулом такого розвитку $є$ досягнення успіху групою. Розширення сфери діяльності групи починається, коли група шукає зв'язки з іншими людьми, які перебувають у схожій ситуації, ділиться з ними досвідом, допомагає. Самокерована модель має надзвичайно великі можливості для ії̈ використання медичними працівниками в роботі служби «Довіра». Такий підхід дуже ефективний, особливо якщо його метою $є$ досягнення змін у житті споживачів ін'єкційних наркотиків.

Важливим $є$ проведення до- та післятестового консультування осіб, які проходять тестування на виявлення антитіл до ВІЛ, надання їм необхідної інформації з проблем ВІЛ-інфекції/СНІД відіграють важливу роль у попередженні розповсюдження цієї інфекції серед молоді [1]. Консультування - це добровільна конфіденційна цілеспрямована співбесіда між особою, яка звернулася за роз'ясненням, та медичним працівником - консультантом, який надає інформаційно-консультативну допомогу. Метою консультування $\epsilon$ обговорення завдань тестування; оцінка ступеня ризику зараження ВІЛ; визначення емоційних та поведінкових реакцій, можливих наслідків обізнаності особи про свій позитивний щодо ВІЛ статус; обговорення доцільності надання нею інформації про свій ВІЛ-позитивний статус іншим особам; оволодіння навичками безпечної поведінки, запобігання поширенню ВІЛ-інфекції; надання психологічної та інформаційної підтримки; зменшення стресового навантаження.

Особа, яка звертається за консультуванням, повинна: отримати достовірну інформацію про ВІЛінфекцію та психологічну підтримку; ознайомитись зі способами та засобами зниження ризику зараження; отримати необхідну інформацію про технічні аспекти тестування та практичне значення результатів його проведення; отримати інформацію про існуючі державні та недержавні медичні, психологічні, юридичні та соціальні служби, установи, організації, які надають допомогу особам, які її потребують.

Медичні працівники у службі «Довіра» ставили перед собою такі завдання, а саме:

- надавали індивідуальні соціально-медичні, психологічні, правові, інформаційні консультації;

- розповсюджували серед клієнтів інформаційнопросвітницькі матеріали; 
- інформували клієнтів про безпечну статеву поведінку, безпечне вживання наркотиків, можливість проходження тестування на ВІЛ/СНІД;

- розробляли заходи щодо спонукання клієнтів до відмови від ін'єкційного вживання наркотиків;

- проводили обмін та утилізацію використаних шприців, забезпечували клієнтів засобами захисту.

До позитивного досвіду роботи служби «Довіра» можна віднести:

- привернення уваги населення до проблем, пов'язаних із поширенням епідемії ВІЛ та формування безпечної поведінки відносно вживання наркотиків і зараження ВІЛ - через діяльність служб по роботі з ін'єкційними споживачами наркотиків та членами їхніх сімей;

- залучення до діяльності служб медичних працівників. Так, наприклад, без налагодження співпраці 3 медичними закладами було б неможливо відвідування ВІЛ-інфікованих вагітних жінок, які є споживачами ін'єкційних наркотиків;

- залучення до мобільної роботи волонтерів із числа ВІЛ-позитивних людей, споживачів наркотиків,

\section{СПИСОК ЛІТЕРАТУРИ}

1. Основні напрямки роботи, навички та уміння волонтера програми «Зменшення шкоди серед осіб, які вживають наркотики ін'єкційним шляхом» / за ред. Б. П. Лазоренка, І. М. Пінчук. - К. : Центр соціальних експертиз, 2015. - 140 с. які на даний момент перебувають у стійкій ремісії, представників релігійних організацій.

У процесі діяльності служб по роботі з ін'єкційними споживачами наркотиків та членами їхніх сімей виникли проблеми:

- низька мотивація клієнтів до користування послугами служби «Довіра»;

- не вдалося залучити споживачів ін'єкційних наркотиків до створення групи взаємодопомоги;

- нестача кваліфікованих медичних фахівців для роботи для надання якісних послуг у сільській місцевості;

- вплив негативного ставлення соціального оточення із числа споживачів ін'єкційних наркотиків до рекомендацій спеціалістів-медиків;

- приховування хімічних залежностей.

Висновки. Результати дослідження свідчать, що діяльність служб по роботі з ін'єкційними споживачами наркотиків $\epsilon$ ефективною. Проведена робота сприяє запобіганню поширення ВІЛ-інфекції, створює умови щодо зменшення кількості ВІЛ-інфікованих серед молодих осіб, які вживають наркотики ін'єкційним шляхом, сприяє залученню клієнтів до реабілітаційних програм.

2. Організація діяльності консультативних пунктів «Довіра» центрами соціальних служб для молоді : методичний посібник / за ред. Б. П. Лазоренка, І. М. Пінчук. К., 2016. -138 с. 